\title{
Histological and Histochemical Studies on the Effects of Methotrexate on the Liver of Adult Male Albino Rat
}

\author{
Estudios Histológico e Histoquímico del Efecto del Metotrexato \\ en el Hígado de Rata Macho Albina Adulta
}

Mohamed Akram Al-Motabagani AL-MOTABAGANI, M. A. Histological and histochemical studies on the effects of mehotrexate on the liver of adult male albino rat.
Int. J. Morphol., 24(3):417-422, 2006.

SUMMARY: Methotrexate (MTX) is widely used in the therapy of various types of malignancy. The present work was designed to investigate the histological and histochemical changes in the liver of albino rat following methotrexate administration.

Fifteen adult male albino rats were used in the present work. They were divided into three main groups: Group I was kept without treatment and served as control. Groups II and III were given intraperitoneal injections of normal saline and MTX, respectively, at a dosage of $(0.5 \mathrm{mg} / \mathrm{Kg})$ twice weekly for total durations of 3,6 and 9 weeks. The rats were sacrificed and the livers were excised and processed for histological and histochemical study.

Examination of sections of the livers of group III showed mononuclear cell infiltration and an increase in the amount of collagen fibers in the portal tracts. There were focal areas of liver cell necrosis with distortion of the normal hepatic architecture. Moreover, there was a gradual and progressive decrease of glycogen content in the hepatocytes. Furthermore, succinic dehydrogenase and alkaline phosphatase activity were also decreased. In addition there was an increase in acid phosphatase activities in the degenerated areas and loss of activities in areas of massive cellular necrosis.

It was concluded that repeated injections of MTX causes hepatic damage of a definite magnitude. This hepatotoxicity progressed with increasing cumulative doses of methotrexate. The present study provided further evidence to the cytotoxic potency of this antifolate.

KEY WORDS: Methotrexate; Hepatocytes; Hepatic lobules; Glycogen; Enzyme activity.

\section{INTRODUCTION}

Methotrexate (MTX) is one of the folic acid antagonist widely used in the therapy of various types of diseases. It is used in the treatment of psoriasis (Thomas \& Aithal, 2005), psoriatic arthritis (Wollima et al., 2001), rheumatoid arthritis in elderly and younger patients (Padeh et al., 1997), acute lymphoblastic leukemia (Aytac et al., 2006), ectopic pregnancy (Chen et al., 2003), inflammatory bowel diseases such as Crohn's disease and ulcerative colitis (Siegel \& Sands, 2005), and chronic inflammatory demyelinating polyradiculoneutopathy (Fialho et al., 2006). The most serious side effect of MTX therapy is hepatic toxicity (Mardini \& Record, 2005). Hersh et al. (1966) reported mild hepatitis, cholestasis, fatty changes, fibrosis and cirrhosis, in patients receiving MTX for malignant disorders. Penalva Polo et al. (2002) reported acute liver failure in a patient with methotrexate therapy. Gong and Gluud (2005) found that the Methotrexate increased mortality in patients with primary biliary cirrhosis.

Al-Ali et al. (2005) examine the effects of high doses of methotrexate on the ultrastructure and metabolic activity of isolated rat livers. Scanning electron microscopy revealed striking changes in the plasma membrane, the microvillar system, intercellular junctions and the sinusoidal endothelium. Transmission electron microscopy revealed disorganized endoplasmic reticulum, dispersion of the polyribosomes, a variety of mitochondrial changes, and glycogen redistribution.

Department of Anatomy, Collage of Medicine, King Faisal University, Dammam, Saudi Arabia. 
However, fewer reports are available describing the histological and histochemical changes in the liver following MTX application (Jaskiewicz et al., 1996). Therefore, the present work was undertaken to further investigate the histological and histochemical changes in the liver as a result of MTX administration.

\section{MATERIAL AND METHOD}

Fifteen adult male albino rats were used in the present study. They were divided into three main groups: Group I (3 rats) was kept without treatment and served as control. Group II consisted of 3 rats; each was given intraperitoneal injections of normal saline at a dosage of $(0.5 \mathrm{mg} / \mathrm{Kg})$ twice weekly for total durations of 3(rat 1), 6(rat 2) and 9(rat 3) weeks. Group III consisted of 9 rats divided equally into three subgroups and injected with MTX (Methotrexate hydrate, Sigma). In each subgroup the rats were injected twice weekly with MTX $(0.5 \mathrm{mg} / \mathrm{Kg})$ for total durations of 3(subgroup 1), 6(subgroup 2) and 9(subgroup 3) weeks. At the end of each selected duration (3, 6 or 9 weeks) rats from groups I, II and III were sacrificed by overdose of anesthesia. The anterior abdominal wall was opened by a midline incision and the livers were explored. From each rat liver specimens were excised and washed several times with normal saline.

From each liver some specimens were processed for paraffin sections and stained with haematoxylin and eosin for general morphology, Mallory's trichrome for collagen fibers and Periodic Acid Schiff (PAS) with diastase control for glycogen (Bancroft \& Gamble, 2002).Other specimens were rapidly frozen by cryo-spray, and five microns thick cryostat sections were cut. The sections were processed to demonstrate enzyme activity. The theory and practice of enzyme histochemistry has been previously descried in detail (Bancroft \& Gamble). Standard dehydrogenase technique with tetrazolium solution was applied to demonstrate activity of succinic dehydrogenase which appeared as bluish- purple formazan deposits, Gomori's calcium method was applied to demonstrate activity of alkaline phosphatase which appeared in the form of brownish-black colour, and Gomori's lead method was applied for acid phosphatase which took the brownish-black colour (Bancroft \& Gamble).

\section{RESULTS}

The results obtained from histological sections of livers of the control and saline-injected rats were similar (Figs. 1A and 1B). The classic liver (hepatic) lobule was hexagonal in shape. At the center of the lobule was the central vein (terminal hepatic venule). The hepatocytes were organized into anastomosing cords or plates, one cell thick, separated by anastomosing hepatic sinusoids. Thehepatocytes had vesicular nuclei and acidophilic cytoplasm. Each cord of hepatocytes was exposed on either side to hepatic sinusoids. The plates of hepatocytes and hepatic sinusoids radiated from the central vein to the periphery of the lobule. The portal tract (triad or area) was located at each corner of the lobule, and was composed of thin connective tissue septum containing few collagen fibers (Fig. 1B). Embedded in the portal tract were a terminal portal venule, a terminal hepatic arteriole, an interlobular bile ductule and fine lymph vessels. Sections stained with PAS showed that the peripheral and mid-lobular hepatocytes contained more glycogen granules than central hepatocytes around the central vein (Fig.1C).

In the present study various techniques of enzyme histochemistry were applied to localize sites of enzyme activity in liver cryostat sections. Strong succinic dehydrogenase activity was detected in the cytoplasm of the hepatocytes, while no activity was detected in the regions of the nuclei (Fig.1D). Mild alkaline phosphatase reaction was detected in the hepatocytes, and strong reaction was detected in the thin endothelial lining of both the hepatic sinusoids and blood vessels of the portal tracts (Fig.1E). Moderate acid phosphatase activity was detected in the hepatocytes (Fig.1F).

The livers of animals treated with repeated injections of MTX showed variable degrees of morphological and pathological changes. These changes were gradual and progressive; they were mainly confined to the portal tracts and the periphery of the hepatic lobules following 3 and 6 weeks of injections, and extended to involve the central zones as well following 9 weeks of injections.

A1. Area of necrosis

A2. Area of glycogen depletion

A3. Area of weak succinic dehydrogenase activity

A4. Area of weak alkaline phosphatase activity

C. Collagen fibers

$\mathrm{CH}$. Central hepatocytes

CV. Central vein(s)

H. Hepatocytes

H1. Hepatocytes with strong acid phosphatase activity

H2. Hepatocytes with weak acid phosphatase activity

N. Nuclei

PH. Peripheral hepatocytes

PT. Portal tract

S. Hepatic sinusoids 
Figs. 1A-1F. Six photomicrograph of sections from the livers of control (group I) and saline-injected (group II) rats.

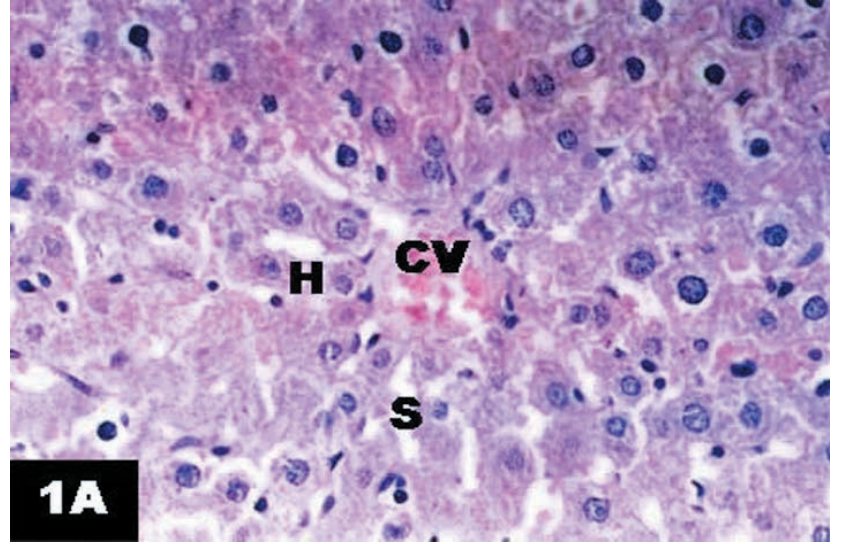

1A. Shows the general morphology of the classic liver (hepatic) lobule. It is roughly hexagonal in shape. At the center of the lobule is the central vein $(\mathrm{CV})$. The hepatocytes $(\mathrm{H})$ are organized into anastomosing cords or plates, one cell thick, separated by anastomosing hepatic sinusoids(S). The plates of hepatocytes and hepatic sinusoids radiate from the central vein to the periphery of the lobule. (H\&E, X400).

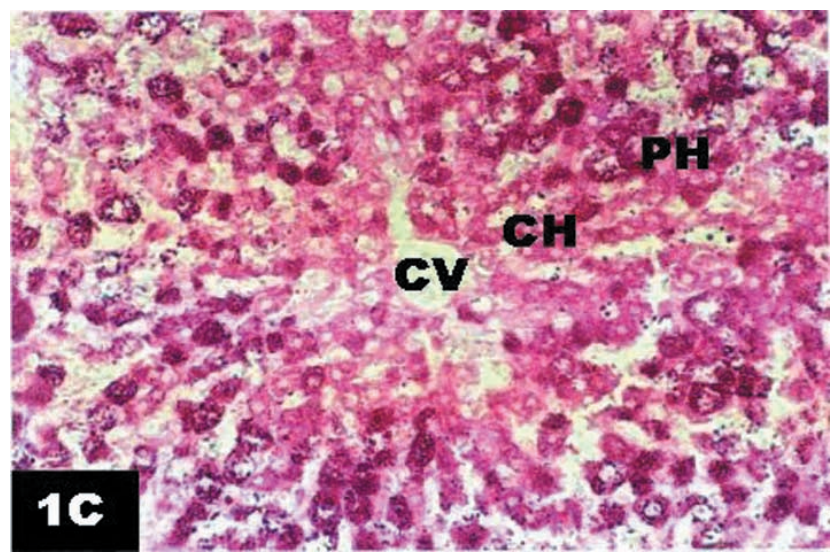

1C. Shows that, within the hepatic lobule, hepatocytes $(\mathrm{PH})$ in the peripheral and mid-lobular areas contain more glycogen than hepatocytes $(\mathrm{CH})$ in the central area around the central vein $(\mathrm{CV})$ (PAS, X200).

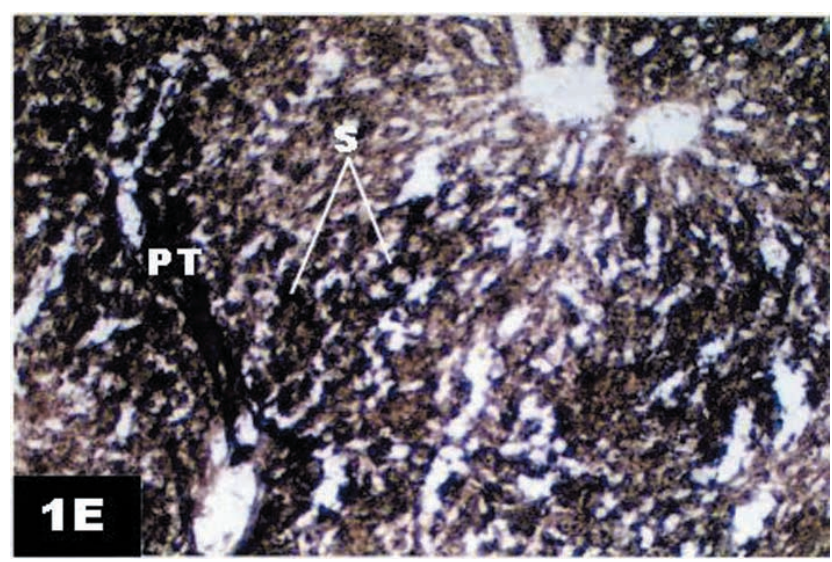

1E. Shows strong alkaline phosphatase activity in the endothelial lining of both the hepatic sinusoids and blood vessels of portal tracts. (Gomori's calcium method, X200).

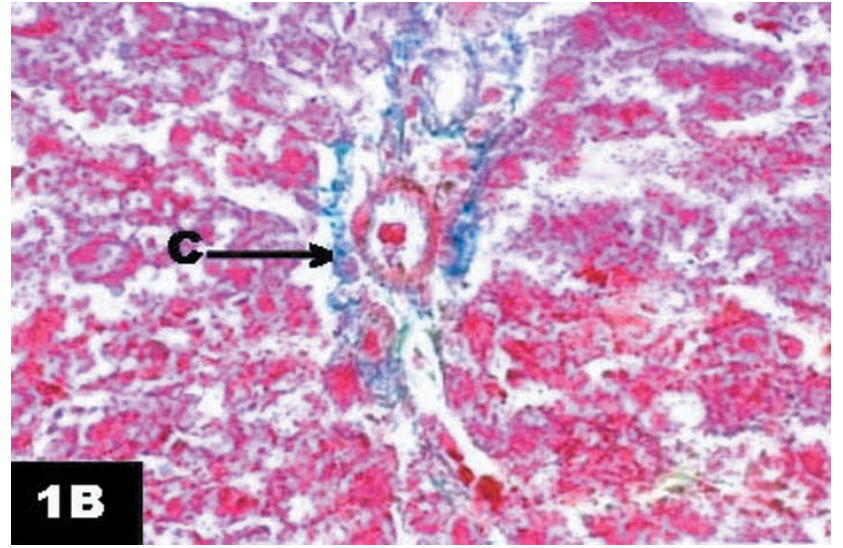

1B. Shows normal distribution of collagen fibers (C), stained blue, around a portal tract. The later contains a terminal portal venule, a terminal hepatic arteriole, an interlobular bile ductule and fine lymph vessels. (Mallory's trichrome, X200).

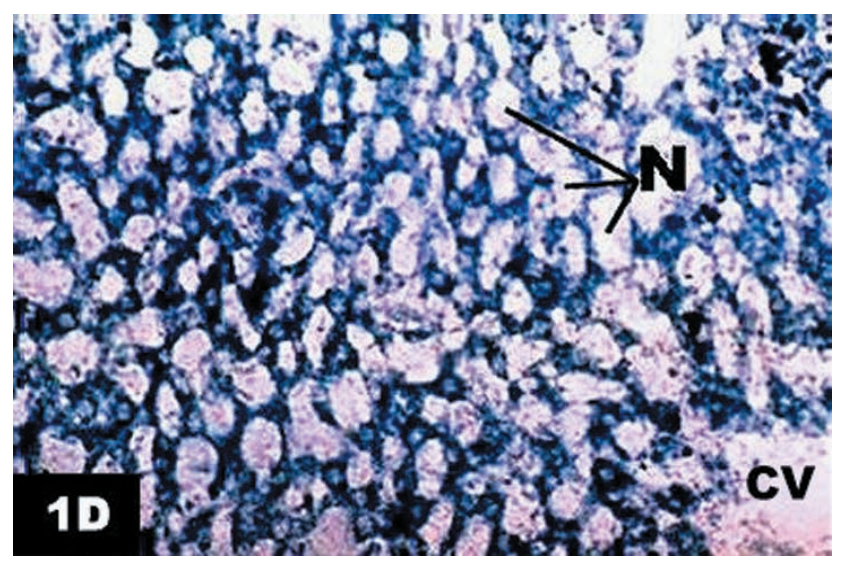

1D. Shows strong succinic dehydrogenase activity in the cytoplasm of the hepatocytes. No activity is detected in the regions of the nuclei (N). (Standard NBT method, X200).

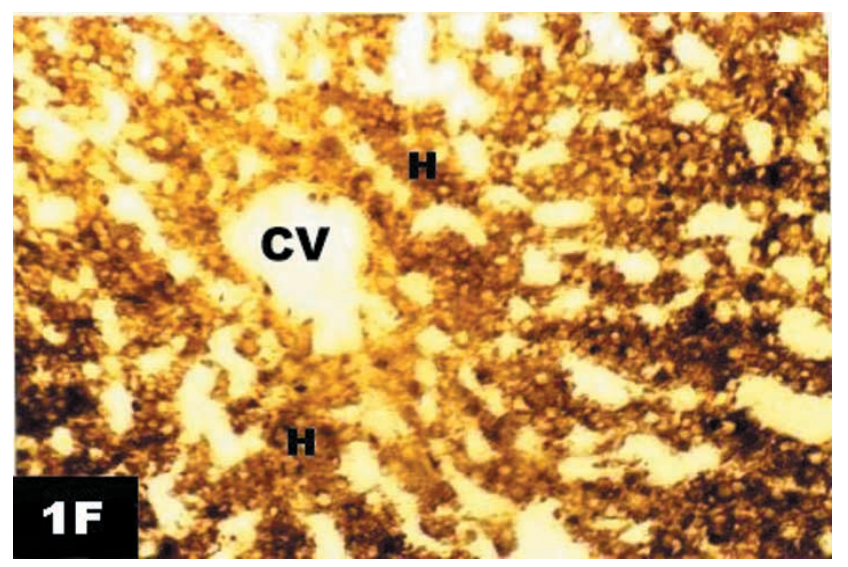

1F. Shows moderate acid phosphatase activity in the hepatocytes. (Gomori's lead method, X200). 
Figs. 2A-2F. Six photomicrograph of sections from the livers of rats following 9 weeks of repeated intraperitoneal injections of MTX (subgroup 3 of group III).

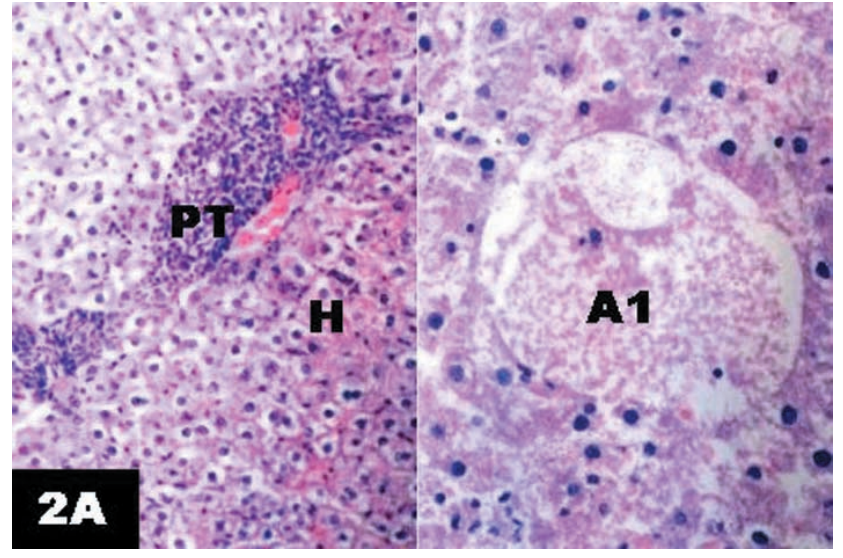

2A. Left field shows heavy cell infiltration around the portal tract (PT) and vacuolation of the cytoplasm of hepatocytes $(\mathrm{H}) ;(\mathrm{H} \& \mathrm{E}$, X200). Right field shows focal area of necrosis (A1) where the cell boundaries were lost with distortion of the normal hepatic architecture (H\&E, X400).

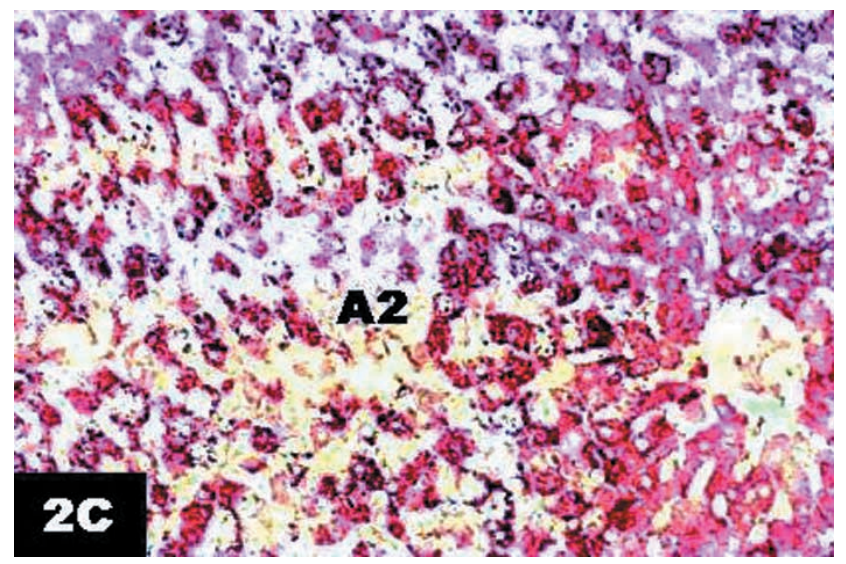

2C. Shows marked glycogen depletion in focal areas (A2) of the hepatic lobule. (PAS, X200).

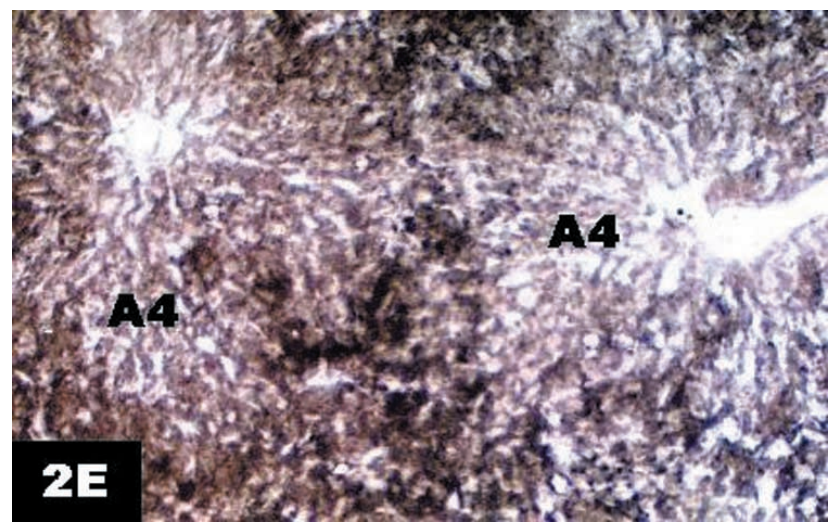

2E. Shows apparent decrease in alkaline phosphatase activity in areas (A4) of two adjacent hepatic lobules. (Gomori's calcium method, X200).

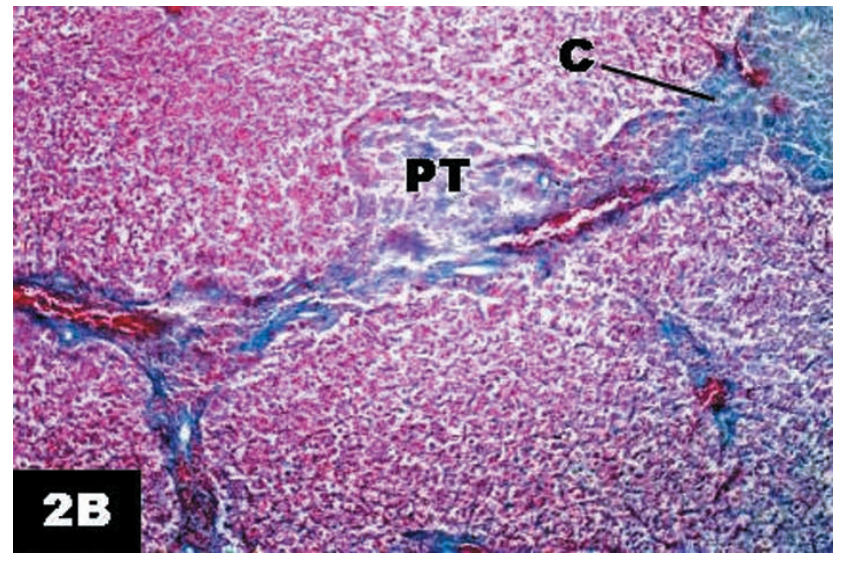

2B. Shows marked increase in collagen fibers (C) around the blood vessels in the portal tract (Mallory's trichrome, X100).

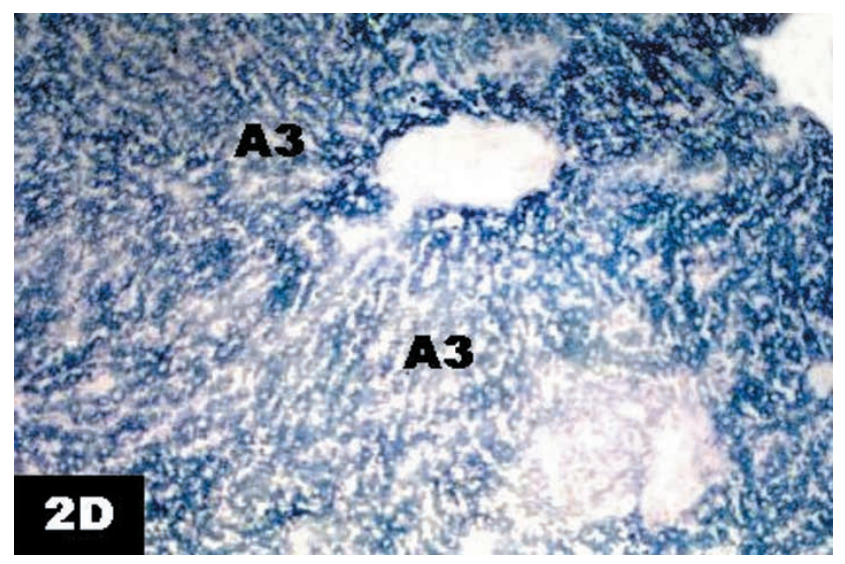

2D. Shows apparent weak succinic dehydrogenase activity in some areas (A3) of the hepatic lobule. (Standard NBT method, X100).

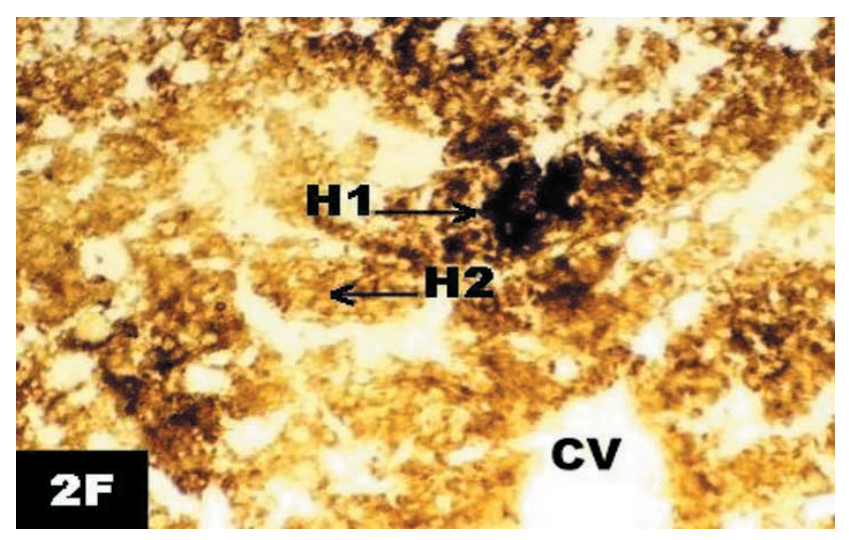

2F. Shows apparent strong acid phosphatase activity in some hepatocytes (H1) and a weak activity in others (H2). (Gomori's lead method, X200). 
Mononuclear cell infiltration was observed mainly in the portal tracts (Fig.2A). The cytoplasm of hepatocytes in the peripheral zones of classic hepatic lobules appeared vacuolated (Fig.2A). Focal areas of liver showed complete destruction leaving necrotic material with distortion of the normal hepatic architecture (Fig 2A). There was an apparent increase in the amount of collagen fibers particularly around blood vessels in portal tract (Fig 2B). Gradual and progressive decrease of glycogen content in the hepatocytes was observed (Fig 2C).

The activity of succinic dehydrogenase in the hepatocytes was progressively decreased and became very weak in some areas (Fig 2D). Marked decrease in alkaline phosphatase activity was also observed (Fig 2E). The acid phosphatase showed a variable activity with a patchy strong reaction in some groups of hepatocytes and a very weak reaction in other groups of cells (Fig 2F).

\section{DISCUSSION}

In this work, the pathological lesions in the form of vacuolation and necrosis were mainly manifested in the peripheral zones of hepatic lobules. However, in late stages, the pathological changes extended to involve the central zones as well. This could be explained by the type of blood circulation inside the hepatic lobule. Normally, the direction of blood flow proceeds from the periphery of the lobule toward the central vein, that is, the flow of blood is centripetal. At the periphery of the lobule, the inlet venules (portal vein) and inlet arterioles (hepatic artery) pierce the periportal hepatocytes limiting plate to open into the sinusoids. Blood percolates within the sinusoids to the central vein and is exposed to the activities of the hepatocytes around the sinusoids. Plasma flows freely through the sinusoidal wall into the perisinusoidal spaces where it is exposed to the various activities of the hepatocytes, and then flows back into the bloodstream. Plasma that remains in the perisinusoidal space becomes lymph. Most of the injected MTX reached the liver through the portal vein and end finally in the terminal portal venules in the portal tracts. Thus, the peripheral hepatocytes became exposed to a higher concentration of the drug more than the central cells.

The mechanism by which MTX causes hepatotoxicity results from binding to the enzyme dihydrofolic reductase, thus preventing conversion of folic acid to its active form, folinic acid. This in turn blocks the synthesis of nucleic acids, certain amino acids and indirectly proteins. This might lead to damage of organelles and plasma membranes of hepatic parenchymal cells interfering with their function and allowing leakage of enzymes (Hersh et al.).

Periportal fibrosis was noticed in this research.
O'Rourke and Eckert (1964) stated that such hepatic fibrosis seemed to be due to direct toxic effects of MTX which induced proliferation of the hepatic fibrous connective tissue. Ros et al., (2002) found mild perisinusoidal fibrosis and by EM identified an increase in collagen fibers in the Disse spaces. Also, Hytiroglou et al., (2004) found that the methotrexate is known to cause hepatic fibrosis in some patients, which might progress to cirrhosis.

In control liver sections, it was observed that the peripheral and midlobular hepatocytes contained more glycogen granules than in central hepatocytes. These findings were previously reported by Cardell et al. (1973) and were explained by the fact that hepatocytes in zone I of liver acinus are able to synthesize glycogen very actively than other zones as they obtained an excellent supply of nutrients and oxygen (Cardell, 1977 and Cormack, 1987). The progressive decrease in glycogen content that noticed after MTX injections might be due to defects in its synthesis as a result of degeneration of the hepatic cells accompanied by damage of mitochondria. Accordingly, reduction of mitochondrial content of the cell will reduce the amount of ATP, the matter which inhibits glycogen formation (Robbins \& Cotran 1999).

As regards the succinic dehydrogenase enzyme, there was progressive reduction of its activity after MTX injection. Robbins \& Cotran explained that by the fact that in degenerative cells there was damage and breakdown of mitochondria. Since succinic dehydrogenase enzyme is a mitochondrial enzyme, reduced mitochondrial content of the cells will reduce their enzyme content.

In the present work, the alkaline phosphatase enzyme activity was progressively decreased after MTX injections. This reduction could be explained by the noticeable damage that affected the endothelial cells lining the blood sinusoids and blood vessels in the portal tracts, which are considered to be the main sites at which the enzyme acts.

There was a gradual increase of the activity of acid phosphatase after MTX injections. This was explained by Hurban et al. (1972) to be a result of increased lysosomal activity and concomitant increase in their enzymes. Focal areas of weak acid phosphatase activity were also observed. This finding is consistence with that of Alpers \& Beckstead (1985), who mentioned that the acid phosphatase activity disappeared in sloughed necrotic and completely damaged tissue while in adjacent non-necrotic tissue it was observed.

From the foregoing it is recommended that when MTX is used therapeutically, the liver functions should be taken into consideration. Patients with previous hepatic diseases should better avoid the use of this drug whenever possible but if its use is necessary, short courses may be advised. 
AL-MOTABAGANI, M. A. Estudios histológico e histoquímico del efecto del metotrexato en el hígado de rata macho albina adulta. Int. J. Morphol., 24(3):417-422, 2006

RESUMEN: El metotrexato es ampliamente usado en la terapia de varias enfermedades malignas. El presente trabajo fue diseñado para investigar los cambios histológicos e histoquímicos del hígado de rata albina, después de administrar dicho fármaco. Se usaron 15 ratas albinas, machos, adultas, que fueron divididas en 3 grupos: El grupo I no tuvo tratamiento correspondiendo al control. A los grupos II y III se les administró, por vía intraperitoneal, una solución salina normal y metotrexato, respectivamente, con una dosificación de $0,5 \mathrm{mg}$ por $\mathrm{Kg}$ de peso, dos veces por semana, con una duración total de 3 , 6 y 9 semanas. Las ratas fueron sacrificadas y los hígados extraídos y procesados para los estudios histológico e histoquímico.

El examen de los hígados del grupo III mostró infiltración celular mononuclear y un incremento en la cantidad de fibras colágenas en la vía portal. Hubo áreas focales de necrosis de células hepáticas con distorsión de la arquitectura hepática normal. Además, hubo un gradual y progresivo decrecimiento del contenido de glicógeno en los hepatocitos. La actividad de deshidrogenasa succínica y fosfatas alcalinas también disminuyó, pero sí hubo un aumento de la actividad de las fosfatasas ácidas en las áreas degeneradas y pérdida de actividades en áreas de necrosis celular masiva.

En conclusión, inyecciones repetidas de metotrexato causan daño hepático de maginitud definida. Esta hepatotoxicidad progresó a medida que las dosis se fueron acumulando. El presente estudio muestra evidencias claras de la potencia citotóxica de este medicamento.

PALABRAS CLAVE: Metotrexato; Hepatocitos; Lóbulos hepáticos; Glicógeno; Actividad enzimática.

\section{REFERENCES}

Al-Ali, S.Y.; Hassan, I.M. \& Sadek, S. Ultrastructural changes in rat livers perfused in vitro and in vivo with a high dose of methotrexate. Histol. Histopathol., 20(4):1131-45, 2005.

Alpers, C. D. \& Beckstead, J.H. Enzyme biochemistry in plastic-embedded sections of normal and diseased kidneys. Am. J. Clin. Pathol., 83(5):605$12,1985$.

Aytac, S.; Yetgin, S. \& Tavil, B. Acute and long-term neurologic complications in children with acute lymphoblastic leukemia. Turk. J. Pediatr., 48(1):1$7,2006$.

Bancroft, J. D. \& Gamble, M. Theory and practice of histological techniques. $5^{\text {th }}$. Ed. Edinburgh. Churchill Livingstone Pub., 2002. pp 172-5, pp 593620

Cardell, R. R. Smooth endoplasmic reticulum in rat hepatocytes during glycogen deposition and depletion. Int. Rev. Cytol., 48: 221-79, 1977.

Cardell, R. R.; Larner, J. \& Babcock, M. B. Correlation between structure and glycogen content of livers from rats on a controlled feeding schedule. Anat. Rec., 177:23-37, 1973.

Chen, Y.X.; Mao, Y.Y.\& Xie, X. Efficacy and side effects of methotrexate in the treatment of ectopic pregnancy .Zhonghua Fu Chan Ke Za Zhi, 38(12):749-51, 2003.

Cormack, D. H. Ham's histology. 9. ed. London. Lippincott Williams \& Wilkins., 1987. pp 520.

Fialho, D.; Chan, Y.C.; Allen, D.C.; Reilly, M.M.\& Hughes, R.A. Treatment of chronic inflammatory demyelinating polyradiculoneutopathy with methotrexate. J. Neurol. Neurosurg. Psychiatry, 77(4):544-7, 2006.

Gong, Y. \& Gluud, C. Methotrexate for primary biliary cirrhosis. Cochrane Database Syst. Rev., 20 (3):CD004385, 2005.

Hersh, E. M.; Wong, V. G.; Handerson, E.S. \& Freireich, E. J. Hepatotoxic effects of methotrexate. Cancer, 19(4):600-6, 1966.

Hruban, Z.; Slesers, A. \& Hopkins. A drug-induced and naturally occurring myloid bodies. Lab. Invest., 27(1):62-70, 1972.

Hytiroglou, P.; Tobias, H.; Saxena, R,; Abramidou, M.; Papadimitriou, C. S. $\&$ Theise, N. D. The canals of hering might represent a target of methotrexate hepatic toxicity. Am. J. Clin. Pathol., 121(3):324-9, 2004.
Jaskiewicz, K.; Voigt, H. \& Blakolmer, K. Increased matrix proteins, collagen and transforming growth factor are early markers of hepatotoxicityin patients on long-term methotrexate therapy. J. Toxicol. Clin. Toxicol., 34(3):301-5, 1996.

Mardini, H. \& Record, C. Detection assessment and monitoring of hepatic fibrosis: biochemistry or biopsy? Ann. Clin. Biochem., 42(6):441-7, 2005.

O'Rourke, R.A. \& Eckert, G.E. Methotrexate-induced hepatic injury in an adult. A case report. Arch. Int. Med., 113:191-4, 1964.

Padeh, S.; Sharon, N.; Schiby, G.; Rechavi, G. \& Passwell, J. H. Hodgkin's lymphoma in systemic onset juvenile rheumatoid arthritis after treatment with low dose methotrexate. J. Rheumatol., 24(10):2035-7, 1997.

Penalva Polo, J. C.; Gomez Andres, A. ; Vela, P. \& Niveiro, M. Acute liver failure in a patient with methotrexate therapy. Rev. Esp. Enferm. Dig., 94(7):440-1, 2002.

Robbins, S. L. \& Cotran, V. Robbins Pathologic Basis of Disease. $7^{\text {th }}$. ed. Philadelphia. WB Saunders Company, 1999. pp 28.

Ros, S.; Juanola, X.; Condom, E.; Canas, C.; Riera, J.; Guardiola, J.; Del Blanco, J.; Rebasa, P.; Valverde, J. \& Roig-Escofet, O. Light and electron microscopic analysis of liver biopsy samples from rheumatoid arthritis patients receiving long-term methotrexate therapy. Scand. J. Rheumatol. , 31(6):330-6, 2002

Siegel, C. A. \& Sands, B.E. Review article: practical management of inflammatory bowel disease patients taking immunomodulators. Aliment. Pharmacol. Ther., 22(1):1-16, 2005.

Thomas, J. A. \& Aithal, G. P. Monitoring liver function during methotrexate therapy for psoriasis: are routine biopsies necessary? Am. J. Clin. Dermatol., 6(6):357-63, 2005.

Wollima, U.; Stander, K. \& Barta, U. Toxicity of methotrexate treatment in psoriasis and psoriatic arthritis-short- and long-term toxicity in 104 patients. Clin. Rheumatol., 20(6):406-10, 2001.

Corespondence to:

Dr. M. A. Motabagani

Chairman and Head

Department of Anatomy, College of Medecine

King Faisal University, P.O. Box 2114

Dammam 31451

Saudi Arabia

Email:drmahm@hotmail.com

Accepted: 22-06-2006 